\title{
Cold-activated brown adipose tissue in healthy men
}

Citation for published version (APA):

van Marken Lichtenbelt, W. D., Vanhommerig, J. W., Smulders, N. M., Drossaerts, J. M., Kemerink, G. J., Bouvy, N. D., Schrauwen, P., \& Teule, G. J. (2009). Cold-activated brown adipose tissue in healthy men. New England Journal of Medicine, 360(15), 1500-8. https://doi.org/10.1056/NEJMoa0808718

Document status and date:

Published: 01/01/2009

DOI:

10.1056/NEJMoa0808718

Document Version:

Publisher's PDF, also known as Version of record

Document license:

Taverne

Please check the document version of this publication:

- A submitted manuscript is the version of the article upon submission and before peer-review. There can be important differences between the submitted version and the official published version of record.

People interested in the research are advised to contact the author for the final version of the publication, or visit the DOI to the publisher's website.

- The final author version and the galley proof are versions of the publication after peer review.

- The final published version features the final layout of the paper including the volume, issue and page numbers.

Link to publication

\footnotetext{
General rights rights.

- You may freely distribute the URL identifying the publication in the public portal. please follow below link for the End User Agreement:

www.umlib.nl/taverne-license

Take down policy

If you believe that this document breaches copyright please contact us at:

repository@maastrichtuniversity.nl

providing details and we will investigate your claim.
}

Copyright and moral rights for the publications made accessible in the public portal are retained by the authors and/or other copyright owners and it is a condition of accessing publications that users recognise and abide by the legal requirements associated with these

- Users may download and print one copy of any publication from the public portal for the purpose of private study or research.

- You may not further distribute the material or use it for any profit-making activity or commercial gain

If the publication is distributed under the terms of Article $25 \mathrm{fa}$ of the Dutch Copyright Act, indicated by the "Taverne" license above, 


\title{
Cold-Activated Brown Adipose Tissue in Healthy Men
}

\author{
Wouter D. van Marken Lichtenbelt, Ph.D., Joost W. Vanhommerig, M.S., \\ Nanda M. Smulders, M.D., Jamie M.A.F.L. Drossaerts, B.S., \\ Gerrit J. Kemerink, Ph.D., Nicole D. Bouvy, M.D., Ph.D., \\ Patrick Schrauwen, Ph.D., and G.J. Jaap Teule, M.D., Ph.D.
}

From the Department of Human Biology, Nutrition and Toxicology Research Institute Maastricht (W.D.M.L., J.W.V., J.M.A.F.L.D., P.S.), the Department of Nuclear Medicine (N.M.S., G.J.K., G.J.J.T.), and the Department of General Surgery (N.D.B.), Maastricht University Medical Center, Maastricht, the Netherlands. Address reprint requests to Dr. van Marken Lichtenbelt at the Department of Human Biology, Maastricht University, P.O. Box 616, 6200 MD, Maastricht, the Netherlands, or at markenlichtenbelt@hb.unimaas.nl.

N Engl J Med 2009;360:1500-8.

Copyright @ 2009 Massachusetts Medical Society.

\section{BACKGROUND}

Studies in animals indicate that brown adipose tissue is important in the regulation of body weight, and it is possible that individual variation in adaptive thermogenesis can be attributed to variations in the amount or activity of brown adipose tissue. Until recently, the presence of brown adipose tissue was thought to be relevant only in small mammals and infants, with negligible physiologic relevance in adult humans. We performed a systematic examination of the presence, distribution, and activity of brown adipose tissue in lean and obese men during exposure to cold temperature. Brown-adipose-tissue activity was studied in relation to body composition and energy metabolism.

\section{METHODS}

We studied 24 healthy men -10 who were lean (body-mass index [BMI] [the weight in kilograms divided by the square of the height in meters], <25) and 14 who were overweight or obese (BMI, $\geq 25)$ - under thermoneutral conditions $\left(22^{\circ} \mathrm{C}\right)$ and during mild cold exposure $\left(16^{\circ} \mathrm{C}\right)$. Putative brown-adipose-tissue activity was determined with the use of integrated ${ }^{18} \mathrm{~F}$-fluorodeoxyglucose positron-emission tomography and computed tomography. Body composition and energy expenditure were measured with the use of dual-energy x-ray absorptiometry and indirect calorimetry.

\section{RESULTS}

Brown-adipose-tissue activity was observed in 23 of the 24 subjects (96\%) during cold exposure but not under thermoneutral conditions. The activity was significantly lower in the overweight or obese subjects than in the lean subjects $(\mathrm{P}=0.007)$. BMI and percentage of body fat both had significant negative correlations with brown adipose tissue, whereas resting metabolic rate had a significant positive correlation.

\section{CONCLUSIONS}

The percentage of young men with brown adipose tissue is high, but its activity is reduced in men who are overweight or obese. Brown adipose tissue may be metabolically important in men, and the fact that it is reduced yet present in most overweight or obese subjects may make it a target for the treatment of obesity. 
T HERE IS EVIDENCE THAT STIMULATING adaptive thermogenesis, defined as the facultative heat produced in response to cold and diet, might serve as a means of preventing or treating obesity ${ }^{1}$; thus, it is of interest to understand the mechanisms underlying adaptive thermogenesis. We previously reported that cold-induced thermogenesis in the absence of shivering accounts for an average of $11.8 \%$ of the resting metabolic rate, with high individual variation. ${ }^{2}$ Individual differences in energy expenditure can have large, long-term effects on body weight. ${ }^{3}$ Several prospective studies have shown that a relatively low energy expenditure predicts a gain in body weight. , $^{4}$ Hence, adaptive thermogenesis may be an attractive target for antiobesity therapies.

Cold-induced thermogenesis and diet-induced thermogenesis have recently been shown to be related, suggesting that they have a similar underlying mechanism. ${ }^{6}$ In small mammals, brown adipose tissue serves as a thermogenic organ, in which mitochondrial respiration is uncoupled from ATP production (through the action of uncoupling protein 1 [UCP1]) to dissipate energy. Although several early anatomical studies suggested that brown adipose tissue is present in adult humans, ${ }^{7-9}$ its physiologic relevance was believed to be marginal for most. ${ }^{9,10}$ In the past few years, however, studies conducted for other reasons that made use of integrated positron-emission tomography and computed tomography (PET-CT) indicated that brown adipose tissue is occasionally present and active in adult humans, ${ }^{11-14}$ with the prevalence ranging from $2.5 \%{ }^{11}$ to $45 \% .{ }^{15}$ Some studies indicate that brown adipose tissue is related to the body-mass index (BMI), ${ }^{15,16}$ and others do not. ${ }^{12,17}$

We systematically examined the presence, distribution, and activity of brown adipose tissue in healthy volunteers in relation to body composition and energy metabolism. The activity of brown adipose tissue was assessed with the use of PET-CT scanning with ${ }^{18} \mathrm{~F}$-fluorodeoxyglucose ( ${ }^{18} \mathrm{~F}-\mathrm{FDG}$ ), body composition with dual-energy x-ray absorptiometry (DEXA), and energy expenditure with indirect calorimetry. Brown adipose tissue was activated by a standardized cold-exposure test.

\section{METHODS}

\section{SUBJECTS AND PROCEDURES}

Between October 2007 and December 2008, we studied 24 healthy male volunteers; 10 were clas- sified as lean (BMI [the weight in kilograms divided by the square of the height in meters], <25), and 14 as overweight or obese (BMI, $\geq 25$ ) (Table 1). The ethics committee of Maastricht University approved the protocol. All subjects provided written informed consent. In addition, a female patient provided written informed consent for the removal of samples of brown adipose tissue and white adipose tissue during surgery for multinodular goiter.

Subjects were studied in the morning, from approximately 9 a.m. to 1 p.m., after an overnight fast beginning at 10 p.m. the night before. During the experiment, all subjects wore standardized clothing $(0.49$ clo, which is a unit of measure for the insulating properties of clothing). In a climate chamber, the subjects rested in a supine position under thermoneutral conditions $\left(22^{\circ} \mathrm{C}\right)$ for 1 hour and were then exposed to mild cold $\left(16^{\circ} \mathrm{C}\right)$ for 2 hours. After 1 hour of exposure to cold, the PET tracer ${ }^{18} \mathrm{~F}-\mathrm{FDG}$ was administered intravenously, and scanning was performed after the second hour of exposure to cold. Three subjects with relatively high levels of brown-adiposetissue activity underwent an additional PET study in thermoneutral conditions in order to determine whether brown adipose tissue was activated only after cold exposure.

The PET-CT scanning protocol (Gemini TF PET-CT, Philips) included confirmation of the serum glucose level and the intravenous injection of $2 \mathrm{mCi}(74 \mathrm{MBq})$ of ${ }^{18} \mathrm{~F}-\mathrm{FDG}$. Subjects rested comfortably, with the head, neck, and shoulders supported from the outset of the experiment until imaging began. Imaging was performed in threedimensional mode, with emission scans of 6 minutes per bed position. Six to seven bed positions per subject were needed to cover the areas where brown adipose tissue is usually found. Imaging started with a low-dose CT scan (30 mAs), immediately followed by a PET scan. The scanner was equipped with time-of-flight electronics, which allows the use of a relatively low amount of radioactivity $(2 \mathrm{mCi})$. The resulting total radiation dose from the low-dose CT scan and the injected radioactive tracer was approximately $2.8 \mathrm{mSv}$. The CT scan was used for attenuation correction and localization of the ${ }^{18} \mathrm{~F}-\mathrm{FDG}$ uptake sites. Both image sets were reconstructed in transaxial, coronal, and sagittal images with a slice thickness of $4 \mathrm{~mm}$. Two nuclear-medicine physicians interpreted the PET-CT images using PMOD soft- 


\begin{tabular}{|c|c|c|c|}
\hline Characteristic & $\begin{array}{l}\text { Lean Subjects } \\
\qquad(\mathrm{N}=10)\end{array}$ & $\begin{array}{l}\text { Overweight or Obese } \\
\text { Subjects }(\mathrm{N}=14)\end{array}$ & P Value ${ }^{\prime}$ \\
\hline Age (yr) & & & 0.58 \\
\hline Mean & $24.3 \pm 3.6$ & $23.5 \pm 3.4$ & \\
\hline Range & $20-32$ & $18-30$ & \\
\hline Body mass (kg) & & & $<0.001$ \\
\hline Mean & $78.1 \pm 9.2$ & $102.0 \pm 17.5$ & \\
\hline Range & $66.0-95.3$ & $76.5-136.5$ & \\
\hline Height (m) & & & 0.99 \\
\hline Mean & $1.83 \pm 0.09$ & $1.83 \pm 0.06$ & \\
\hline Range & $1.75-2.02$ & $1.74-1.94$ & \\
\hline BMI & & & $<0.001$ \\
\hline Mean & $23.2 \pm 1.2$ & $30.3 \pm 4.2$ & \\
\hline Range & $21.3-24.5$ & $25.4-38.7$ & \\
\hline Body fat (\%) & & & $<0.001$ \\
\hline Mean & $16.2 \pm 5.1$ & $27.3 \pm 7.4$ & \\
\hline Range & $9.4-25.1$ & $16.9-41.8$ & \\
\hline
\end{tabular}

* Plus-minus values are means \pm SD. BMI denotes body-mass index, calculated as the weight in kilograms divided by the square of the height in meters.

$\uparrow P$ values are based on unpaired t-tests.

$\checkmark$ The percentage of body fat was determined with the use of dual-energy $x$-ray absorptiometry. was measured in the small intestine with the use of a telemetric pill (HQ). In three subjects (two lean and one overweight), the core-temperature measurement failed.

The protocol for temperature (mildly cold, $16^{\circ} \mathrm{C}$ ) was validated earlier. ${ }^{22}$ Every 15 minutes, each subject was asked whether he had experienced shivering. Body composition was measured with the use of a DEXA whole-body scanner (QDR 4500A, Hologic).

To ascertain whether brown adipose fat in the supraclavicular region could be identified with classic microscopy and an immunofluorescence assay for UCP1, samples were obtained during surgery for a multinodular goiter in a 46-yearold woman with normal thyroid function (body mass, $72 \mathrm{~kg}$; height, $1.72 \mathrm{~m}$; thyroid-stimulating hormone, $1.7 \mathrm{mU}$ per milliliter; and free thyroxine, $12.8 \mathrm{pmol}$ per liter [1.0 ng per deciliter]). Biopsy samples of both brown and white adipose tissues were obtained from the supraclavicular region on the right side. In this area, both fat types were observed in patches measuring approximately $0.5 \mathrm{~cm}^{3}$. Sections (5 $\mu \mathrm{m}$ thick) were fixed for 15 minutes with $3.7 \%$ formaldehyde in phosphatebuffered saline, and UCP1 was detected with the use of rabbit polyclonal human UCP1 antiserum and with goat antirabbit fluorescein isothiocyanate as the secondary antibody, together with the nuclei-staining dye 4,6-diamidino-2-phenylindole ( $0.5 \mathrm{mg}$ per milliliter).

2007). Brown-adipose-tissue activity (measured in kilobecquerels) and brown-adipose-tissue volume (measured in cubic centimeters) were quantified in the region of interest by autocontouring the brown-adipose-tissue areas with a set threshold.

Energy expenditure was measured by means of a respiratory gas analyzer with the use of a ventilated hood system (Oxycon, Jaeger). The resting metabolic rate was corrected for fat-free mass by means of linear regression, since $80 \%$ of individual differences in energy expenditure can be explained by fat-free mass. ${ }^{18}$ The residuals of the regression between energy expenditure and fatfree mass were added to the average energy expenditure. Skin temperatures were measured continually at 16 positions by means of iButtons (type DS1921H, Maxim). ${ }^{19}$ The mean skin temperature was calculated with a 14-point method (ISO-9886). ${ }^{20}$ Underarm-fingertip temperature gradients were calculated to obtain an estimate of blood flow in the fingers. ${ }^{21}$ Core temperature

\section{STATISTICAL ANALYSIS}

Data are reported as means \pm SD. Data analysis was performed with the use of SPSS software, version 11, and Statview SE for MacIntosh (SAS Institute). Comparisons were made by means of a paired t-test (for findings under thermoneutral conditions as compared with mild cold exposure) and an unpaired t-test (for findings in lean men as compared with overweight or obese men). Linear regression analyses were conducted to identify correlations between variables. For the relation between brown-adipose-tissue activity and body composition, exponential curve fitting was applied; therefore, log (brown-adipose-tissue activity) was plotted against body composition (BMI or percentage of body fat). Cook's distance values that were larger than 0.5 and Studentized deleted residuals larger than 4.0 were considered to be outliers. P values of less than 0.05 were considered to indicate statistical significance. 


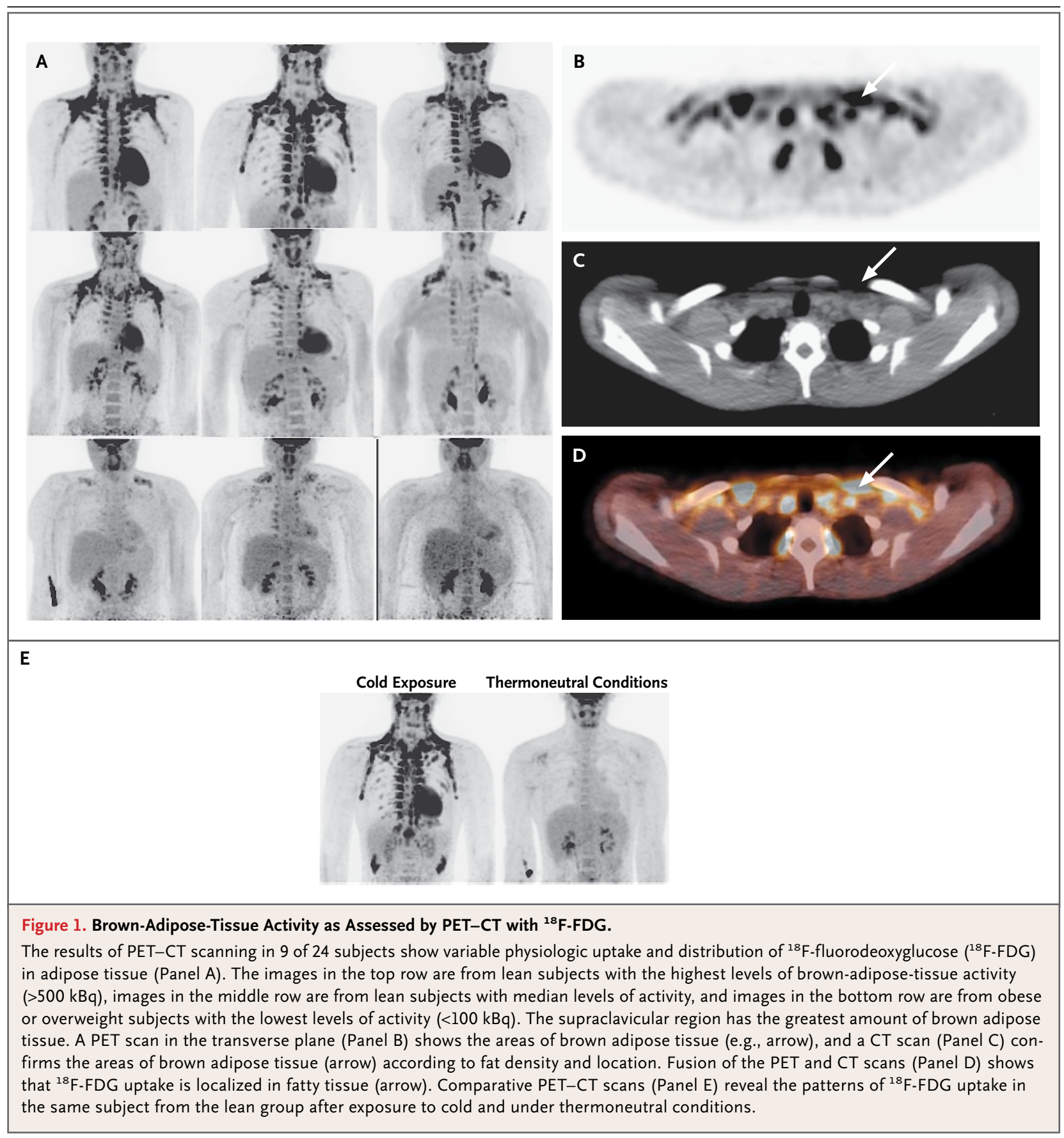

\section{RESULTS}

Twenty-three of the 24 subjects had definite, albeit highly variable, amounts of ${ }^{18} \mathrm{~F}-\mathrm{FDG}$ activity in the neck, supraclavicular region, chest, and abdomen (Fig. 1A). On the fused PET-CT images, the activity was located not in muscle tissue but in fat tissue, which was therefore considered to be brown adipose tissue (Fig. 1B through 1D). All lean subjects and 13 of the 14 overweight or obese subjects had evidence of brown-adiposetissue activity in response to cold exposure. Mean brown-adipose-tissue activity was significantly lower in the overweight or obese subjects $(102 \pm 93$ $\mathrm{kBq})$ than in the lean subjects $(428 \pm 394 \mathrm{kBq})$ $(\mathrm{P}=0.007)$ (Table 2). The volume of brown adipose 


\begin{tabular}{|c|c|c|c|c|c|}
\hline \multirow[t]{2}{*}{ Variable } & \multirow[t]{2}{*}{$\begin{array}{l}\text { Lean Group } \\
\qquad(N=10)\end{array}$} & \multirow[t]{2}{*}{$\begin{array}{l}\text { Overweight or Obese } \\
\text { Group }(\mathrm{N}=14)\end{array}$} & \multirow[t]{2}{*}{$\begin{array}{l}\text { P Value, Lean } \\
\text { vs. Obese }\end{array}$} & \multicolumn{2}{|c|}{ P Value, $22^{\circ} \mathrm{C}$ vs. $16^{\circ} \mathrm{C}$} \\
\hline & & & & Lean Subjects & $\begin{array}{l}\text { Overweight or } \\
\text { Obese Subjects }\end{array}$ \\
\hline BAT activity $(\mathrm{kBq}) \uparrow$ & $428 \pm 394$ & $102 \pm 93$ & 0.007 & & \\
\hline BAT volume $\left(\mathrm{cm}^{3}\right) \dagger$ & $130 \pm 98$ & $77 \pm 69$ & 0.14 & & \\
\hline Resting metabolic rate $(\mathrm{MJ} / 24 \mathrm{hr}$ ) & & & & $<0.001$ & $<0.001$ \\
\hline Thermoneutral conditions & $8.46 \pm 0.93$ & $8.16 \pm 0.29$ & 0.27 & & \\
\hline Cold exposure & $9.62 \pm 1.36$ & $9.56 \pm 0.66$ & 0.89 & & \\
\hline Respiratory quotient $\left(\mathrm{VCO}_{2} / \mathrm{VO}_{2}\right) \ddagger$ & & & & 0.009 & $<0.001$ \\
\hline Thermoneutral conditions & $0.832 \pm 0.039$ & $0.833 \pm 0.049$ & 0.94 & & \\
\hline Cold exposure & $0.798 \pm 0.027$ & $0.789 \pm 0.031$ & 0.46 & & \\
\hline \multicolumn{6}{|l|}{ Body temperature $\left({ }^{\circ} \mathrm{C}\right)$} \\
\hline Core & & & & 0.06 & 0.02 \\
\hline Thermoneutral conditions & $36.7 \pm 0.3$ & $36.6 \pm 0.2$ & 0.49 & & \\
\hline Cold exposure & $36.8 \pm 0.3$ & $36.8 \pm 0.2$ & 0.80 & & \\
\hline Skin & & & & $<0.001$ & $<0.001$ \\
\hline Thermoneutral conditions & $32.5 \pm 0.6$ & $32.4 \pm 0.4$ & 0.64 & & \\
\hline Cold exposure & $29.2 \pm 0.8$ & $28.7 \pm 0.6$ & 0.06 & & \\
\hline Gradient, core and skin & & & & $<0.001$ & $<0.001$ \\
\hline Thermoneutral conditions & $4.2 \pm 0.6$ & $4.3 \pm 0.4$ & 0.86 & & \\
\hline Cold exposure & $7.5 \pm 0.8$ & $8.1 \pm 0.7$ & 0.08 & & \\
\hline Gradient, arm-finger & & & & $<0.001$ & $<0.001$ \\
\hline Thermoneutral conditions & $-1.9 \pm 1.4$ & $-3.5 \pm 1.7$ & 0.03 & & \\
\hline Cold exposure & $3.4 \pm 2.8$ & $4.6 \pm 2.8$ & 0.29 & & \\
\hline
\end{tabular}

* Plus-minus values are means \pm SD. BAT denotes brown adipose tissue, $\mathrm{VCO}_{2}$ volume of carbon dioxide produced, and $\mathrm{VO}_{2}$ volume of oxygen consumed.

$\uparrow$ BAT activity and BAT volume were measured after cold exposure.

$\checkmark$ Both $\mathrm{VCO}_{2}$ and $\mathrm{VO}_{2}$ are measured in liters per minute.

tissue tended to be lower in the overweight or obese subjects than in the lean subjects, but the difference was not significant $(\mathrm{P}=0.14)$. Only one subject had no ${ }^{18} \mathrm{~F}-\mathrm{FDG}$ uptake in areas of adipose tissue. This subject had the highest BMI (38.7) and percentage of body fat (41.8\%). In all subjects with brown-adipose-tissue activity, the area with the most evidence of activity was the supraclavicular region (Fig. 1). However, other sites also had substantial putative brown-adiposetissue activity.

There was no detectable brown-adipose-tissue activity in the three subjects who were retested under thermoneutral conditions (Fig. 1E). Brownadipose-tissue activity was recorded in Subject 2 (Fig. 1A) at $856.5 \mathrm{kBq}$ during exposure to cold and $0 \mathrm{kBq}$ in thermoneutral conditions, in Subject 3 at $587.2 \mathrm{kBq}$ during cold exposure and $0 \mathrm{kBq}$ in thermoneutral conditions, and in Subject 4 at $250.0 \mathrm{kBq}$ during cold exposure and $0 \mathrm{kBq}$ thermoneutral conditions.

Studies of brown adipose tissue obtained from the supraclavicular region during surgery in the patient with multinodular goiter revealed the presence of UCP1 (Fig. 2). The protein was not detected in white adipose tissue taken from the same region in this patient.

On exposure to cold, all subjects had an insulative response (a reduction of skin temperature relative to core temperature) and a metabolic response (an increase in heat production) (Table 2). Body core temperature increased slightly in re- 
sponse to cold exposure, with lean subjects having an increase of $0.13 \pm 0.16^{\circ} \mathrm{C}(\mathrm{P}=0.06$ for the comparison with body), and obese or overweight subjects an increase of $0.16 \pm 0.22^{\circ} \mathrm{C}(\mathrm{P}=0.02)$. The mean skin temperature dropped significantly in both study groups, by $3.4 \pm 0.9^{\circ} \mathrm{C}$ in the lean subjects and by $3.7 \pm 0.5^{\circ} \mathrm{C}$ in the overweight or obese subjects. The core skin temperature gradient increased significantly during cold exposure as compared with the gradient under thermoneutral conditions $(\mathrm{P}<0.001)$ (Table 2). The underarmfingertip gradient also increased during cold exposure, indicating vasoconstriction in the skin of the extremities. ${ }^{21}$ The resting metabolic rate adjusted for fat-free mass was $8.46 \pm 0.93 \mathrm{MJ}$ per 24 hours in the lean subjects and 8.16 $\pm 0.29 \mathrm{MJ}$ per 24 hours in the overweight or obese subjects. The rate increased significantly during exposure to cold in both groups $(\mathrm{P}<0.001$ for both comparisons) (Table 2), with much individual variation, ranging from 5 to $30 \%$. No shivering was reported.

Nonlinear regression analysis showed that the activity of whole-body brown adipose tissue was negatively correlated with $\mathrm{BMI}(\mathrm{r}=-0.60, \mathrm{P}=0.002)$ and percentage of body fat $(\mathrm{r}=-0.60, \mathrm{P}=0.001)$ (Fig. 3A and 3B). There was no correlation between brown-adipose-tissue activity and age, and in a stepwise regression analysis, BMI but not age was significantly associated with brown-adiposetissue activity.

The change in distal temperature from thermoneutral conditions to cold exposure was related to brown-adipose-tissue activity ( $\mathrm{r}=0.41, \mathrm{P}=0.04$ ), suggesting that a higher level of activity is associated with a smaller decrease in mean skin temperature and that brown-adipose-tissue activity may contribute to the regulation of body temperature by increasing the production of body heat. However, we did not find a significant relation between cold-induced thermogenesis and brownadipose-tissue activity. The resting metabolic rate was positively correlated with brown-adipose-tissue activity both under thermoneutral conditions $(\mathrm{r}=$ $0.56, \mathrm{P}=0.005$; with one outlier removed, $\mathrm{r}=0.64$, $\mathrm{P}=0.001$ ) (Fig. 4) and during cold exposure $(\mathrm{r}=0.40, \mathrm{P}=0.05$; with the same outlier removed, $\mathrm{r}=0.46, \mathrm{P}=0.03$ ), indicating that brown-adiposetissue activity is involved in energy metabolism. The core temperature under thermoneutral conditions was also positively correlated with brownadipose-tissue activity $(\mathrm{r}=0.48, \mathrm{P}=0.03)$.
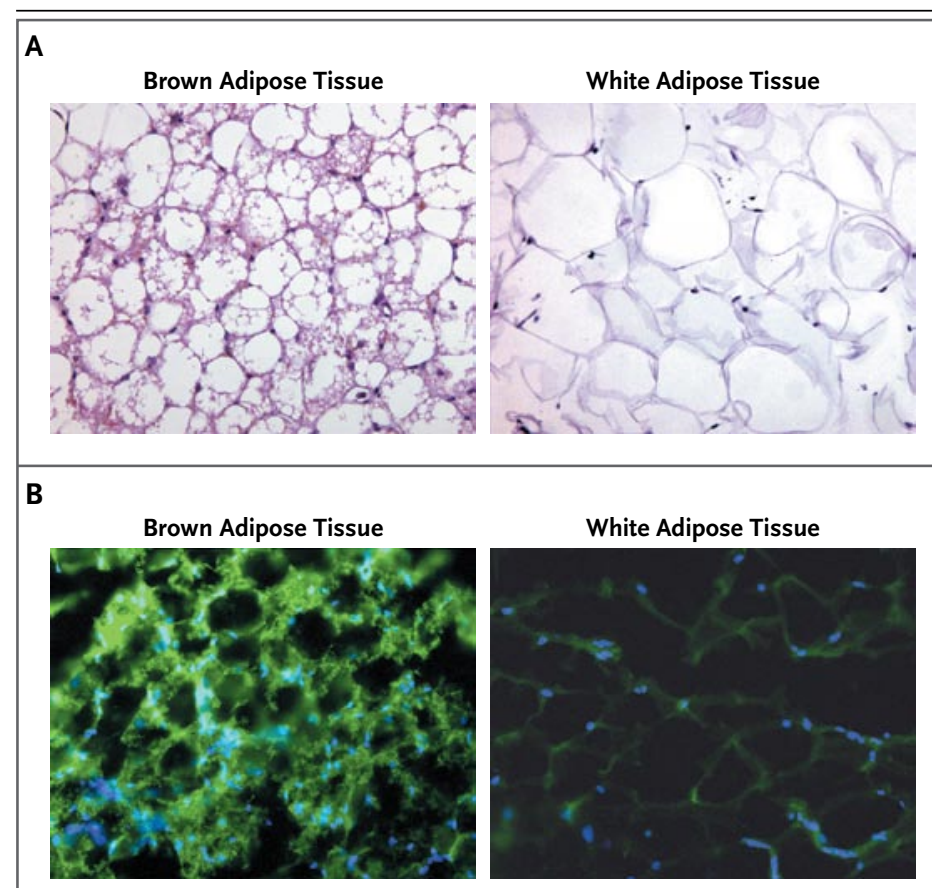

C
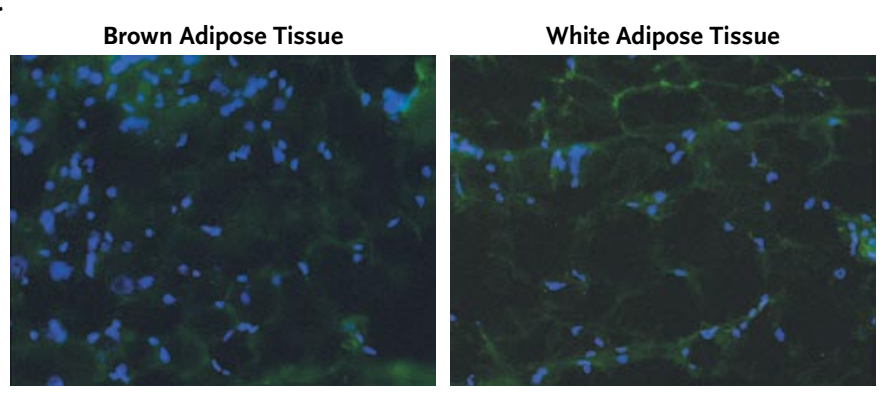

Figure 2. Specimens of Brown and White Adipose Tissue from the Supraclavicular Region in a 46-Year-Old Woman.

Specimens stained with hematoxylin and eosin (Panel A) show granular cytoplasm containing mitochondria and multiple fat vacuoles, which are characteristic of brown adipose tissue, and a single large lipid vacuole in each white fat cell. The use of immunofluorescence assay for an antibody to uncoupling protein 1 (UCPl) together with the nuclei-staining dye 4',6-diamidino-2phenylindole (Panel B) shows positive immunostaining for UCPl (green) in brown adipose tissue but not in white adipose tissue. Control specimens were stained with 4',6-diamidino-2-phenylindole in phosphate-buffered saline (Panel C).

\section{DISCUSSION}

We observed a very high rate of occurrence of brown adipose tissue in normal young men (>95\%). In tissue samples taken from the supraclavicular area of a surgical patient, an immunofluorescence assay revealed the presence of UCP1, confirming the presence of brown adipose tissue 


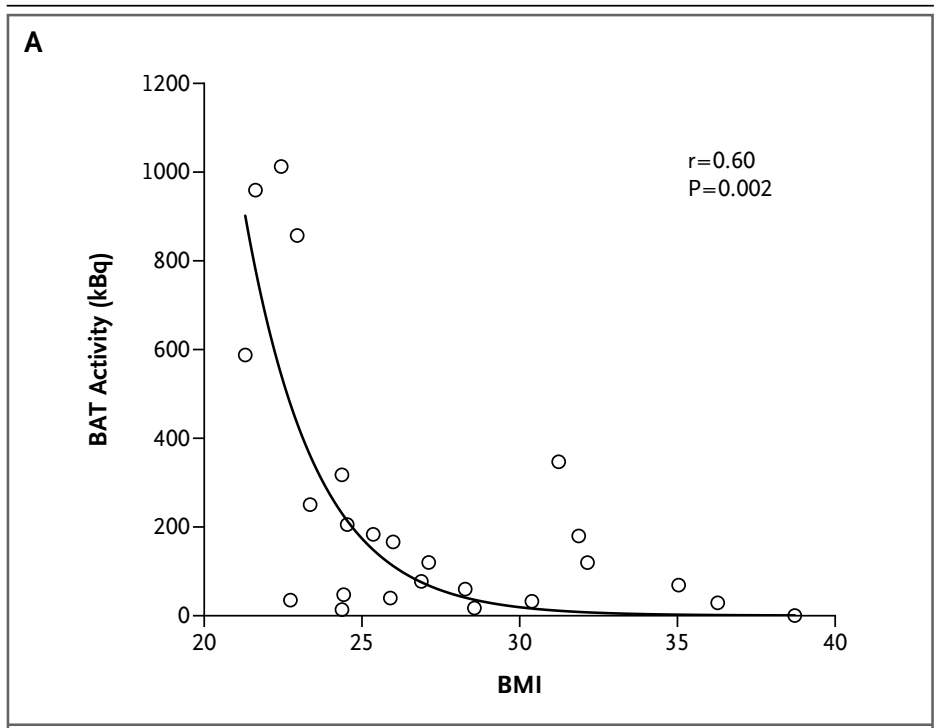

B

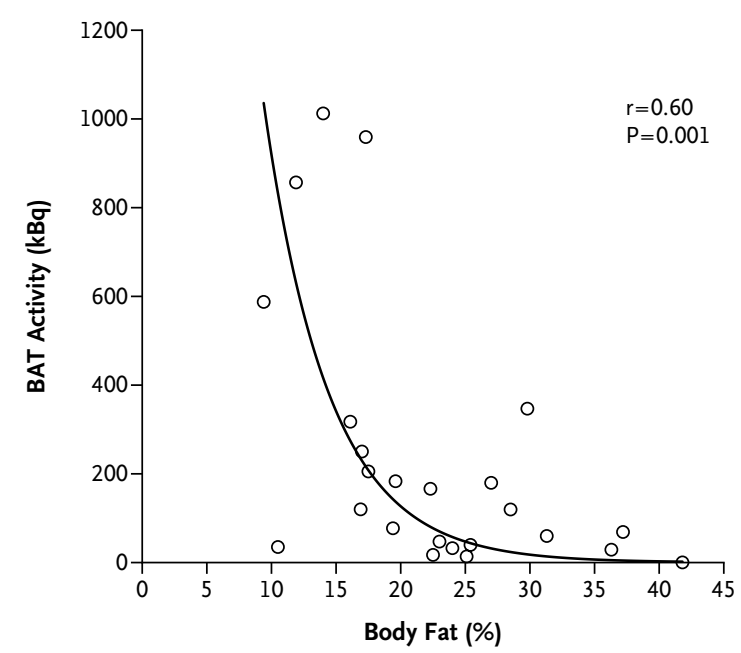

Figure 3. Activity of Brown Adipose Tissue in Relation to BMI and Percentage of Body Fat.

Panel A shows the relation between brown-adipose-tissue (BAT) activity and BMI. Panel B shows the relation between BAT activity and percentage of body fat. brown-adipose-tissue activity and BMI as well as between brown-adipose-tissue activity and percentage of body fat. However, only one obese subject had no brown-adipose-tissue activity. This finding indicates that it may be possible to increase brown adipose tissue in most overweight or obese men, and we speculate that methods of increasing brown adipose tissue in such men may be of therapeutic interest. Studies of the effects of regular exposure to cold, weight-loss diets, and increased physical activity on brown-adiposetissue activity will also be of interest.

In our study, the rate of detection and level of activity of brown adipose tissue were much higher than those in earlier studies. The high detection rate in the current study is most likely due to the use of a standardized test for cold exposure. Previous studies measured brown adipose tissue in patients with cancer and related the occurrence of brown adipose tissue to outside temperatures or the season. ${ }^{23}$ One early study used ephedrine rather than cold to stimulate brownadipose-tissue activity in men. ${ }^{9}$ However, that study focused on perirenal brown adipose tissue, assuming that all depots have the same level of activity.

Our study showed that in all the subjects, the level of brown-adipose-tissue activity was highest in the supraclavicular region. However, other sites with substantial brown-adipose-tissue activity were evident. Most sites have been described in previous autopsy studies ${ }^{8}$ or in studies using PET-CT scanning with ${ }^{18}$ F-FDG. ${ }^{14}$ A second reason for the high incidence of brown-adiposetissue activity in our study is the relatively young age of our subjects, ranging from 18 to 32 years. It is likely that the amount of brown adipose tissue decreases with age, ${ }^{17}$ although no relation between brown-adipose-tissue activity and age was observed in our study.

The relation between brown-adipose-tissue activity and BMI observed in our study is similar to the results of previous studies, which showed that the level of brown-adipose-tissue activity was highest in subjects with a low BMI. ${ }^{15,16}$ However, other studies, which were retrospective and were not designed to assess brown-adipose-tissue activity, did not confirm this finding. ${ }^{12,17}$

Brown-adipose-tissue activity was negatively correlated with a change in distal skin temperature, suggesting that the activity during cold exposure was involved in the immediate response 
to cold temperatures. Thus, subjects with the highest level of brown-adipose-tissue activity had the lowest drop in distal temperature, suggesting that these subjects were able to maintain core body temperature through an increase in body heat. However, contrary to our expectation, there was no significant relation between brown-adipose-tissue activity and cold-induced thermogenesis. The most likely reason is that other tissues, such as skeletal muscle,${ }^{1}$ may be involved in the thermogenic response. Indeed, we recently found that mitochondrial uncoupling in skeletal muscle is significantly related to cold-induced adaptive thermogenesis in humans. ${ }^{24}$ Given the findings of an earlier study, in which subjects were exposed to cold for 1 hour, ${ }^{2}$ we expected less cold-induced thermogenesis in the group of overweight or obese subjects than in the lean group, but the groups did not differ significantly in this respect. Even though the overweight or obese subjects had an increase in thermogenesis on exposure to cold that was similar to the increase in the lean subjects, they had less brown-adiposetissue activity (or none).

Recent studies conducted at the molecular level have identified a mechanism by which PR domain containing 16 (PRDM16), a zinc-finger protein selectively expressed in brown adipose tissue, can induce gene expression in brown adipose tissue while suppressing it in white adipose tissue, thereby controlling the induction of brown adipose tissue. ${ }^{25,26}$ Moreover, there is recent evidence that brown adipose tissue is more closely related to skeletal muscle than to white adipose tissue. ${ }^{27,28}$ A putative shared lineage between brown adipose tissue and skeletal muscle may provide clues about the origins of stem cells that lead to the formation of brown fat and to adaptive thermogenesis.

Our study suggests that the relatively high level

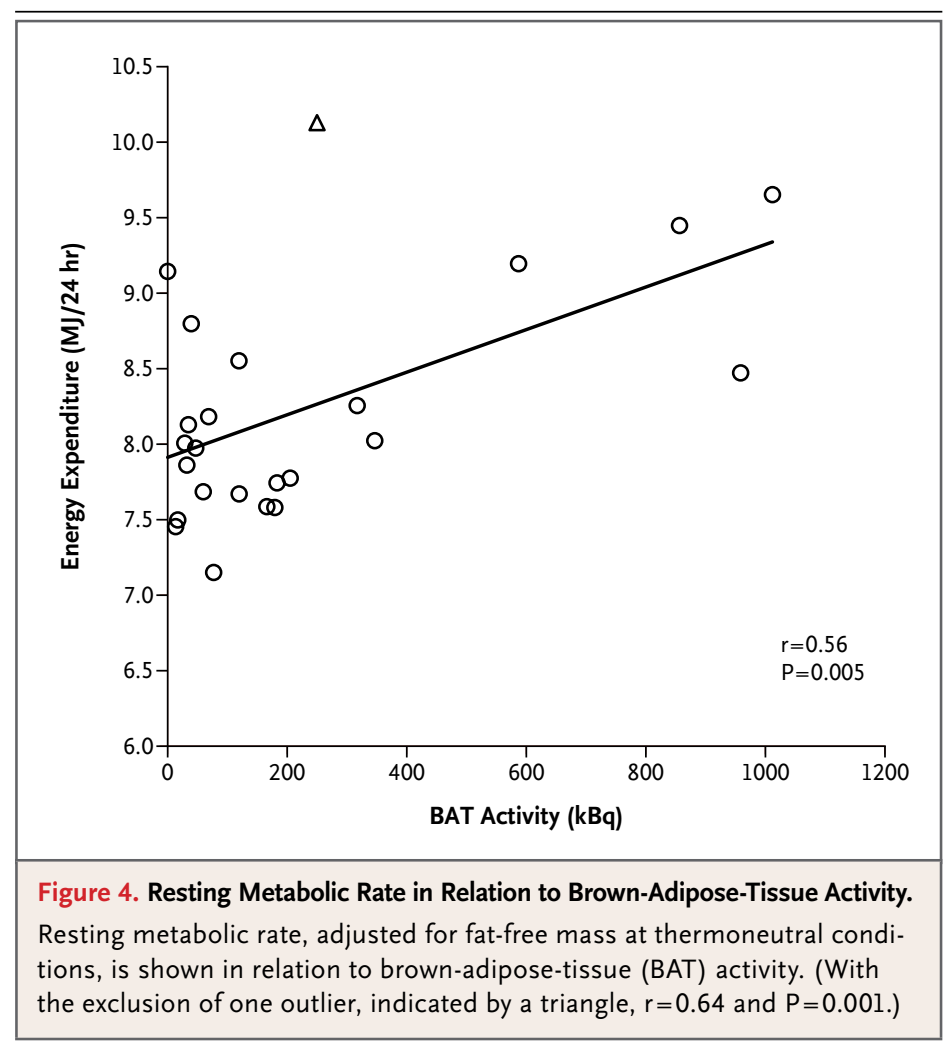

of brown-adipose-tissue activity in young men is related to energy metabolism. Further work is needed to understand brown-adipose-tissue activity in relation to skeletal-muscle metabolism; ideally, this work will be conducted along with molecular studies that may delineate the relative contribution of each to adaptive thermogenesis.

No potential conflict of interest relevant to this article was reported.

We thank Loek Wouters, Paul Schoffelen, and Emiel Beijer for their technical support; David Creytens and Gert Schaart for the analyses of biopsy specimens; and the members of our Temperature Literature Club, especially Sander Wijers, for helpful suggestions.
REFERENCES

1. Lowell BB, Spiegelman BM. Towards a molecular understanding of adaptive thermogenesis. Nature 2000;404:652-60.

2. Claessens-van Ooijen AM, Westerterp KR, Wouters L, Schoffelen PF, van Steenhoven AA, van Marken Lichtenbelt WD. Heat production and body temperature during cooling and rewarming in overweight and lean men. Obesity (Silver Spring) 2006;14:1914-20.

3. Christiansen E, Garby L. Prediction of body weight changes caused by changes in energy balance. Eur J Clin Invest 2002; 32:826-30.

4. Ravussin E, Lillioja S, Knowler WC, et al. Reduced rate of energy expenditure as a risk factor of body weight gain. $\mathrm{N}$ Engl J Med 1988;318:467-72.

5. Griffiths M, Payne PR, Stunkard AJ, Rivers JPW, Cox M. Metabolic rate and physical development in children at risk of obesity. Lancet 1990;336:76-8.

6. Wijers SLJ, Saris WHM, van Marken Lichtenbelt WD. Individual thermogenic responses to mild cold and overfeeding are closely related. J Clin Endocrinol Metab 2007;92:4299-305.

7. Huttunen P, Hirvonen J, Kinnula V. The occurrence of brown adipose tissue in outdoor workers. Eur J Appl Physiol Occup Physiol 1981;46:339-45.

8. Heaton JM. The distribution of brown adipose tissue in the human. J Anat 1972; 112:35-9.

9. Astrup A, Bulow J, Madsen J, Christensen NJ. Contribution of BAT and skel- 
etal muscle to thermogenesis induced by ephedrine in man. Am J Physiol 1985;248: E507-E515.

10. Himms-Hagen J. Does brown adipose tissue (BAT) have a role in the physiology or treatment of human obesity? Rev Endocr Metab Disord 2001;2:395-401.

11. Hany TF, Gharehpapagh E, Kamel EM, Buck A, Himms-Hagen J, von Schulthess GK. Brown adipose tissue: a factor to consider in symmetrical tracer uptake in the neck and upper chest region. Eur J Nucl Med Mol Imaging 2002;29:1393-8.

12. Cohade C, Osman M, Pannu HK, Wahl RL. Uptake in supraclavicular area fat ("USA-Fat"): description on 18F-FDG PET/CT. J Nucl Med 2003;44:170-6.

13. Yeung HW, Grewal RK, Gonen M, Schoder H, Larson SM. Patterns of (18)FFDG uptake in adipose tissue and muscle: a potential source of false-positives for PET. J Nucl Med 2003;44:1789-96.

14. Nedergaard J, Bengtsson T, Cannon B. Unexpected evidence for active brown adipose tissue in adult humans. Am J Physiol Endocrinol Metab 2007;293:E444E452.

15. Rousseau C, Bourbouloux E, Campion $\mathrm{L}$, et al. Brown fat in breast cancer patients: analysis of serial (18)F-FDG PET/CT scans. Eur J Nucl Med Mol Imaging 2006;33:78591.
16. Chiba S, Katsuragi I, Simada T, et al. Evaluation of human brown adipose tissue using positron emission tomography, computerised tomography and histochemical studies in association with body mass index, visceral fat accumulation and insulin resistance. Obes Rev 2006;7:Suppl 2: 87. abstract.

17. Sturkenboom MGG, Franssen EJF, Berkhof J, Hoekstra OS. Physiological uptake of [18F]fluorodeoxyglucose in the neck and upper chest region: are there predictive characteristics? Nucl Med Commun 2004;25:1109-11.

18. Ravussin E, Lillioja S, Anderson TE, Christin L, Bogardus C. Determinants of 24-hour energy expenditure in man: methods and results using a respiratory chamber. J Clin Invest 1986;78:1568-78.

19. van Marken Lichtenbelt WD, Daanen HAM, Wouters L, et al. Evaluation of wireless determination of skin temperature using iButtons. Physiol Behav 2006;88 489-97.

20. ISO 9886 . Evaluation of thermal strain by physiological measurements. Geneva: International Standards Organization, 2004

21. Rubinstein EH, Sessler DI. Skin-surface temperature gradients correlate with fingertip blood flow in humans. Anesthesiology 1990;73:541-5.
22. van Ooijen AMJ, van Marken Lichtenbelt WD, van Steenhoven AA, Westerterp K. Seasonal changes in metabolic and temperature responses to cold air in humans. Physiol Behav 2004;82:545-53.

23. Cohade C, Mourtzikos KA, Wahl RL. "USA-Fat": prevalence is related to ambient outdoor temperature-evaluation with 18F-FDG PET/CT. J Nucl Med 2003;44: 1267-70.

24. Wijers SLJ, Schrauwen P, Saris WHM, van Marken Lichtenbelt WD. Human skeletal muscle mitochondrial uncoupling is associated with cold induced adaptive thermogenesis. PLoS ONE 2008;3(3):e1777.

25. Kajimura S, Seale P, Tomaru T, et al. Regulation of the brown and white fat gene programs through a PRDM16/CtBP transcriptional complex. Genes Dev 2008; 22:1397-409.

26. Seale P, Kajimura S, Yang W, et al. Transcriptional control of brown fat determination by PRDM16. Cell Metab 2007; 6:38-54.

27. Seale P, Bjork B, Yang W, et al. PRDM16 controls a brown fat/skeletal muscle switch. Nature 2008;454:961-7.

28. Cannon B, Nedergaard J. Developmental biology: neither fat nor flesh. Nature 2008;454:947-8.

Copyright $\odot 2009$ Massachusetts Medical Society. in a public trials registry. The members of the International Committee of Medical Journal Editors (ICMJE) will consider most clinical trials for publication only if they have been registered (see N Engl J Med 2004;351:1250-1).

Current information on requirements and appropriate registries is available at www.icmje.org/faq.pdf. 